\title{
sciendo
}

\section{Trnavský Execír. Historická monografia špecifickej mestskej štvrte [Execír in Trnava. Historical Monograph of a Specific Urban District]}

\section{TAŤÁNA SOUČKOVÁ}

Department of Historical Sciences and Central European Studies, University of Ss. Cyril and Methodius in Trnava, Slovakia tatana.souckova@ucm.sk

Kopánka means in the Slovak language "a place where something is being dug from the ground". This urban toponym is connected with one of the districts of the city of Trnava, the so-called "Little Rome", as it is often nicknamed thanks to many churches spread all around the city centre together with its historical importance for the Hungarian Roman Catholic Church in the era of Ottoman invasion during the 16th and 17th centuries. However, this is not the history, which would the Kopánka district identify with. It was not until the 19th century when Trnava started to open its centre to people from the outskirts, so they could freely pass through the city walls and become more involved in the life of this ancient Hungarian royal city. Back then Kopánka could be characterized as a working-class district, where rather poor, sometimes even socially excluded people lived. In the late modern period, another name for Kopánka appeared - Execír, meaning "a place, where the army trains". Both names for this urban district of Trnava are included in the title of a new historical monograph dedicated to the history of "Kopánka - Execír" in Trnava and its inhabitants.

The authors, Martina Bocánová, Klaudia Mišovičová, Martin Priečko and Peter Sokolovič more or less follow the pattern used in the previous book about Kopánka, which was published in 2016. Unlike the first edition, the actual monograph is a work of four historians 
and ethnologists instead of the previous three. Moreover, Klaudia Mišovičová and Peter Sokolovič are new to the collective of authors, and their contributions significantly widen the range of information provided about Kopánka.

The first chapter written by Peter Sokolovič describes the historical development of Kopánka starting in prehistoric times and moving on towards the 20th century. Some of the major turning points in the development of the district are mentioned along with interesting details about the changing character of the social and economic milieu of Kopánka. As the main source of information, the author uses previous scholarly works about Kopánka (most importantly from Jozef Šimončič) and combines them with his archival research on Trnava's modern history. The chapter is thoroughly elaborated, however, the text contains some minor stylistic and linguistic errors. Perhaps there will be an opportunity to correct these several editorial mistakes in the future editions of the book.

The following chapter by Klaudia Mišovičová is dedicated to the process of the relocation of people from the Orava region to Trnava. The arrival of new inhabitants from Orava took place in the 1940s and the 1950s since the dam was being built in the territory of their villages, so they were forced to leave their homeland forever. By finding a new home in Kopánka the people from Orava have strongly contributed to the shaping of a new social structure within the district. The second chapter of the monograph shows a deep insight into the process of relocation suggesting its many social implications. Taking into account the overall focus of the text it would seem more logical to intertwine the chapter with the fourth chapter from Martina Bocánová, which is aimed at day-to-day life of Kopánka's inhabitants characterizing their social, economic and religious background.

The urban changes of the Kopánka district have been a research object of Martin Priečko, who based his chapter on detailed field research along with analysis of archival documents and old maps. Priečko's text is a gripping description of the urban development of Kopánka, including the explanation of the etymology of its name, which reflects the digging of clay for the production of clay bricks in the local brickyard. An included list of the street topography of "old Kopánka" at the end of the chapter is especially beneficial.

The fourth and final chapter by Martina Bocánová represents a vivid description of the life of Kopánka's inhabitants in the 19th and 20th centuries adding some very interesting details through the authentic informants' memories collected during the field research. Bocánová gradually covers all the key areas of the social life in Kopánka stressing the most important aspects which have shaped the lives of several generations of the inhabitants of the district. However, it is this chapter that might have been connected with the text of Klaudia Mišovičová, as both authors refer to similar topics (the arrival of the people from Orava). 
Every monograph focused on a specific district, village, town or even a region should not be just a scholarly work, it should be comprehensive to people living in the particular location. It should serve its purpose as a text for the locals, who will go through the pages over and over again searching for the mentions about the things and places they know or they have heard about from their family members. The book about Kopánka is exactly what would anyone interested in the district's history appreciate. It is full of old photographs and maps and most importantly, it tells the story of Kopánka in a way anybody can associate with. Kopánka - Execír in Trnava is a perfect example of a book from the people, who know how to write local history, for the people who are part of this history themselves.

\section{Reviewed Book}

Bocánová Martina, Mišovičová Klaudia, Priečko Martin, Sokolovič Peter. 2021. Trnavský Execirr. Historická monografia špecifickej mestskej štvrte. Bratislava: Národopisná spoločnost' Slovenska, $144 \mathrm{p}$. 